\title{
Education, Human Capital and Economic Growth: Empirical Research on 55 Countries and Regions (1960-2009)
}

\author{
Ying Wang, Shasha Liu* \\ School of Government, Beijing Normal University, Beijing, China \\ Email: *sunnyliu awesome@163.com
}

Received 24 March 2016; accepted 26 April 2016; published 29 April 2016

Copyright (C) 2016 by authors and Scientific Research Publishing Inc.

This work is licensed under the Creative Commons Attribution International License (CC BY). http://creativecommons.org/licenses/by/4.0/

(c) (i) Open Access

\begin{abstract}
This article constructed a panel data model to investigate the effect of education human capital on economic growth, using the latest education data of 55 countries and regions from 1960 to 2009. Meantime, by subdividing education human capital into higher education, secondary education and primary education, it also examines the effect of different education level on economic growth. Furthermore, while introducing health human capital into the model, we explored the influence of different economic development level and some important historical events. The result shows that in general, education human capital has a significant positive impact on economic growth. The positive impact of higher education on economic growth is especially significant, however, the primary education and secondary education does not have a significant impact on economic growth; as for human capital, life expectancy and per capita GDP growth also showed a significant positive correlation.
\end{abstract}

\section{Keywords}

Economic Growth, Human Capital, Education, Health

\section{Introduction}

In the era of knowledge economy, the key to international competition is high quality human capital. China, as the world's largest developing country, in order to improve its comprehensive national power, needs to settle a primary problem first - to decide what kind and which level of education should be the priority of the educational development strategy, considering the current limited resources. Thus, the accompanying is a theoretical question

*Corresponding author.

How to cite this paper: Wang, Y. and Liu, S.S. (2016) Education, Human Capital and Economic Growth: Empirical Research on 55 Countries and Regions (1960-2009). Theoretical Economics Letters, 6, 347-355.

http://dx.doi.org/10.4236/tel.2016.62039 
that must be answered: what is the relationship between education and economic growth? What kind of education makes the largest contribution to economic growth?

In theory, education can improve labor quality, drive the spread of new knowledge and improve labor's ability to introduce, imitate and apply advanced technologies. However, the conclusion of empirical research is uncertain [1]. There are two reasons for this. First, researchers choose different measurement index for human capital. Most scholars have used adult literacy, school enrollment and other indicators to calculate human capital. However, adult literacy can not cover the mathematics and logical reasoning capacity, which actually ignores other forms of education besides basic literacy. In the meantime, school enrollment is also not a good choice since it can not represent human capital properly as there is a lag between school enrollment and the real labor in the market.

Second, sufficient evidence for the relationship is not available because transnational studies on large simple are rare. Since the purpose of this article is to explore the essential law which is reflected from the sample difference and if we take provincial data as sample, it would be difficult to distinguish the differences as the provincial policies that affect education and economic growth are similar. Therefore, to figure out the real relationship between education and economic growth, the research should be conducted based on the unit of country.

Health and education are the two cornerstones of human capital. However, most studies narrowly equal human capital to education, which may not only underestimate the impact of human capital, but also overestimate the role of education by attributing the influence of other forms of human capital such as health to education. Therefore, when considering the impact of education on economic growth, we must exclude the impact of health and other forms of human capital.

Unlike domestic scholars who have focused on the analysis of provincial data, this article selected sample data from 55 countries and regions during 1960-2009, use educational data re-estimated by Barro and Lee, measuring each country's educational human capital by the average years of education. Furthermore, in order to explore the influence of different education level on economic growth, we subdivide education human capital into higher education, secondary education and primary education. Meantime, we introduced health human capital into the model, using life expectancy to measure the health factors in human capital, in order to figure out the impact of human capital on economic while also take health human capital into account. In order to control the impact of the different degree of economic development and some major historic events, we set up virtual variables to control the differences between developed and developing countries, as well as the impact of the oil crisis.

\section{Literature Review}

As one of the core issues in the study of economic growth, the inner relationship between human capital and economic growth has drawn a lot of attention. However, Argument broadly exists in the academic circles.

A lot of scholars believe that human capital and labor production has a significant positive relationship, placing particular emphasis on the role of education on economic growth. Angel de la fuente [2] verified this relationship by using Cobb Douglas production function and data from EU countries. The results shows that with the average years of schooling for each additional year, the labor productivity in the EU countries will be increased by $6.2 \%$ due to the promotion of scientific and technological progress, and the average years of schooling for each additional year may bring long-term economic growth of $3.1 \%$. Afrooz et al. [3] also examined the role of human capital on labor productivity in food industries of Iran over the period of 1995-2006. The results show that education has a positive and significant effect on labor productivity. Aggrey \& Joseph's study [4] of East African manufacturing firms shows that the average education level is positively associated with labor productivity. Using the panel data of 10 developed and 10 developing countries, Sonmez \& Sener [5] found that that education human capital contribute to the economic growth in both developing and developed countries.

On the contrary, some scholars argue that human capital has no promoting effect on labor productivity [6]. Bils \& Klenow [7] claimed that the role of human capital is exaggerated, and the actual impact is not significant. Vandenbussche [8] studied the effect of different components of human capital, using data of 19 OECD countries during 1960-2000. Dividing the effect of human capital into two parts: imitation and innovation, he found that it was the human capital with higher education, rather than the average human capital, that had significant promoting effect on total factor productivity (TFP) and in addition, the promoting effect of primary education in developed economies is not obvious. Some other scholars believe that the relationship between human capital 
and economic growth is uncertain. Mamuneas [9] and other scholars argue that from the microscopic point of view, an increase in human capital can promote economic growth, however, the results is not clear while analyzing from the macroscopic perspective.

Since the existing empirical results are paradoxical, a further and deeper examination on the relationship between education human capital and economic growth is extremely necessary. Besides, as a country, the investment in education is subject to resource constraints, therefore, we need to set up the investment priorities of all levels of education. Thus studies that explore the effect of different level of education on economic growth is needed. This article analyzed the impact of education on economic growth by constructing a theoretical model where health, education and other factors that affect economic growth are also introduced. On this basis, it further investigated the three different impact of primary, secondary and higher education on economic growth respectively, trying to provide a reference for the development of China's education development strategy.

\section{Empirical Analysis}

\subsection{Theoretical Model}

Using Cobb-Douglas production function, we can construct a Solow model which includes human capital:

$$
Y=A K^{\alpha} H^{1-\alpha}
$$

wherein, $Y$ represents the total output; $A$ represents technology stock; $K$ represents physical capital stock; $H$ is human capital stock, which is composed of two parts: education capital $E$ and health capital $M$.

$$
H=E^{\lambda} M^{1-\lambda}
$$

wherein, $\lambda$ is the parameter, and in the process of generating human capital, the substitution elasticity of education capital and health capital is 1.

We can transform (1) to:

$$
\operatorname{In}(Y / L)=\operatorname{In} A+\alpha \operatorname{In}(K / L)+(1-\alpha) \operatorname{In}(H / L)
$$

or

$$
\text { Iny }=\operatorname{In} A+\alpha \operatorname{In} k+(1-\alpha) \operatorname{In} h
$$

wherein, $y$ represents the per capita GDP of the labor force; $k$ is physical capital per capita of the working population; $h$ represents per capita human capital, composed by the average years of schooling and life expectancy.

$$
h=\left(\mathrm{e}^{\theta_{1} S_{1}} \mathrm{e}^{\theta_{2} S_{2}} \mathrm{e}^{\theta_{3} S_{3}}\right)^{\lambda} m^{1-\lambda}
$$

Take (4) into (3), we have:

$$
\text { Iny }=\operatorname{In} A+\alpha \operatorname{In} k+(1-\alpha)(1-\lambda) \operatorname{In} m+(1-\alpha)\left(\lambda \theta_{1} S_{1}+\lambda \theta_{2} S_{2}+\lambda \theta_{3} S_{3}\right)
$$

wherein, $m$ represents per capita health, $\mathrm{e}^{\theta_{i} S_{i}}$ represents per capita education ( $\theta_{i}$ represents the coefficient of the i-th level of education; $S_{i}$ represents the $i$-th years of education, $i=(1,2,3)$, respectively represents the level of primary, secondary and higher education)

The hypothesis of this article is that human capital is positively related to economic growth. And as the two most important components of human capital, both education capital and health capital have significant positive effect on economic growth. Compared to primary and secondary education, higher education has more significant positive effects.

\subsection{Data and Variables}

The sample consists of 55 countries on five continents. Table 1 lists the names of these countries and regions.

Data of GDP per capita comes from Groningen Growth and Development Center (http://www.ggdc.net), expressed by the constant PPP price in 2000. Human capital consists of two parts: one part is the average education years (data comes from the research of professor Barro and Lee [10], http://www.barrolee.com/), the other part is health capital, represented by life expectancy (data comes from Word Bank Data Center, http://data.worldbank.org.cn/indicator/SP.DYN.LE00.IN). Material capital is expressed by the investment share 
Table 1.55 countries and regions.

\begin{tabular}{|c|c|c|c|c|}
\hline Austria & Ireland & Spain & Pakistan & Zimbabwe \\
\hline Belgium & Italy & Sweden & The Philippines & Bolivia \\
\hline Denmark & Netherlands & Switzerland & Singapore & Brazil \\
\hline Finland & Norway & Britain & Sri Lanka & Chile \\
\hline France & Portugal & Bangladesh & Syria & Columbia \\
\hline Germany & Jamaica & China & Thailand & Ecuador \\
\hline Greece & Costa Rica & Hong Kong & Turkey & New Zealand \\
\hline Kenya & Ghana & India & Egypt & Venezuela \\
\hline Korea & Mali & Indonesia & Peru & Canada \\
\hline Malaysia & South Africa & Japan & Uruguay & Mexico \\
\hline Australia & Tunisia & Zambia & Guatemala & U.S.A \\
\hline
\end{tabular}

of per capita GDP which was translated by the constant purchasing power parity in 2005 (data comes from Database of Pennsylvania State University International Center, http://pwt.econ.upenn.edu).

We set up some virtual variables to control the impact of different degrees of economic development and some major historic events. Virtual variable 1 represents whether it's developed country or not. 1 stands for developed country; 0 stands for developing country. Variable 2 represents whether its before 1973 or after 1973. 1 stands for before 1973; 0 stands for after 1973. On this basis, we can analyze the impact of different level of economic development and the impact of oil crisis in 1973.

\subsection{Empirical Analysis}

This article uses data from 1960 to 2009. If we choose one year as time span, the analysis result will be subjected to a large interference. Therefore, we divided 1960-2009 into 10 time span as each time span is 5 years. This article establishes the fixed effect model and random effect model to investigate the impact of human capital on economic development.

To avoid spurious regression, we carried out the unit root test for each variable first. In order to enhance the reliability of the result, four main methods are selected to test the result simultaneously. These four tests were Levin, Lin and Chu test, Im, Pesaran and Shin W test, ADF-Fisher Chi-square test, PP-Fisher Chi-square test. Table 2 listed the test results of these four different methods.

Table 2 shows that the $\mathrm{P}$ values of all variables are less than 0.05 . Therefore, the original hypothesis is rejected. Variables are smooth, no unit root exists.

In order to determine whether there is co-integration relationship between variables, which could lead to spurious regression, this paper conducted a co-integration test on all variables. Results of Kao residual cointegration test show that the ADF statistics is significant at the $5 \%$ level. Therefore, the original hypothesis is rejected. No co-integration relationship exists. It is appropriate to set regression model.

In order to select between the fixed effects model and the random effects model, we conducted Hausman test for the two groups of model (Model 1 and Model 2; Model 3 and Model 4). First, we make original hypothesis: random effects model holds. Then we calculate the Hausman statistic value. As the Hausman statistic value of the two models are respectively 46.673798 and 40.070 , with corresponding probabilities of 0.0000 , so the original hypothesis is rejected. Therefore, it is appropriate to establish a fixed effects model.

For panel model, the lagged endogenous explanatory variables are usually chosen as instrumental variables. On one hand, it can ensure that the endogenous explanatory variables are related to instrumental variables. On the other hand, since the lagged variables have already occurred, therefore its value has been determined for the current period, and it is not related to the disturbance of the current period. To test the endogenous problem, we chose the lag terms of the average years of education and life expectancy as tool variables. Since the fixed effect model is the final analysis model of this paper, therefore we only conducted endogenous test for the fixed effect model. Results show that the Hausman endogenous test statistic of the fixed effect model is -3.388 and -0.911 , the corresponding $\mathrm{P}$ value is not significant, which suggests the fixed effect panel model constructed in this paper does not have the problem of endogenous. 
Specific regression results are shown in Table 3. In all models, physical capital and life expectancy showed a significant positive effect. In Model 2 and Model 4, virtual variable 1 (if it is developed countries or not) showed significantly positive correlation, and virtual variable 2 (if it is before 1973 or after) showed a significant negative correlation. In the regression results of model 1 and model 2, education human capital was represented by the average years of education. According to the results, the average years of education showed a significant positive impact. In the regression results of model 3 and model 4, the human capital of education is refined into the elementary education, the secondary education and the higher education. The coefficient of elementary education years in model 3 is significantly negative, but not significant in model 4 . Secondary education years are not significant in both model 3 and model 4 . Higher education years in model 3 and model 4 are both significant positive.

\subsection{Discussion}

In model 1 and model 2, education human capital is represented by average education years. According to the results, physical capital, life expectancy and average education years all showed a significant positive effect.

Physical capital is the material basis for economic growth and development. Both classical economic growth theory and new economic growth theory regard the material capital as an important factor for economic growth.

Table 2. Unit root test.

\begin{tabular}{|c|c|c|c|c|}
\hline Variables method & $\begin{array}{l}\text { Levin, Lin } \\
\text { and Chu test }\end{array}$ & $\begin{array}{c}\text { Im, Pesaran } \\
\text { and Shin W test }\end{array}$ & $\begin{array}{c}\text { ADF-Fisher } \\
\text { Chi-square test }\end{array}$ & $\begin{array}{c}\text { PP-Fisher } \\
\text { Chi-square test }\end{array}$ \\
\hline Average education years & $-23.5314^{* * *}$ & $-7.91282^{* * *}$ & $230.885^{* * *}$ & $361.503^{* * *}$ \\
\hline Primary education years & $-27.3347^{* * *}$ & $-10.6955^{* * *}$ & $326.654^{* * *}$ & $469.155^{* * *}$ \\
\hline Secondary education years & $-19.5235^{* * *}$ & $-10.6595^{* * *}$ & $262.704^{* * *}$ & $407.425^{* * *}$ \\
\hline higher education years & $-17.8556^{* * *}$ & $-1.68428^{* *}$ & $137.624^{* *}$ & $181.182^{* * *}$ \\
\hline life expectancy & $-19.7695^{* * *}$ & -3.77813 & $221.722^{* * *}$ & $295.691^{* * *}$ \\
\hline physical capital & $-6.51888^{* * *}$ & $-2.00376^{* *}$ & $169.473^{* * *}$ & $164.567^{* * *}$ \\
\hline per capita GDP & $-15.9994^{* * *}$ & $-7.16284^{* * *}$ & $299.482^{* * *}$ & $378.520^{* * *}$ \\
\hline
\end{tabular}

Note: ${ }^{* *}$ indicates a significant level of $5 \%,{ }^{* * *}$ indicates a significant level of $1 \%$.

Table 3. Regression result.

\begin{tabular}{ccccc}
\hline A five-year period & $\begin{array}{c}\text { Fixed effects model } \\
\text { (model 1) }\end{array}$ & $\begin{array}{c}\text { Random effects model } \\
\text { (model 2) }\end{array}$ & $\begin{array}{c}\text { Fixed effects model } \\
\text { (model 3) }\end{array}$ & $\begin{array}{c}\text { Random effects model } \\
\text { (model 4) }\end{array}$ \\
\hline constant & $6.757789^{* * *}$ & $6.724453^{* * *}$ & $8.411602^{* * *}$ & $8.000908^{* * *}$ \\
Life expectancy & $0.036773^{* * *}$ & $0.033443^{* * *}$ & $0.026383^{* * *}$ & $0.025076^{* * *}$ \\
Per capita physical capital & $0.012671^{* * *}$ & $0.012125^{* * *}$ & $0.012234^{* * *}$ & $0.012134^{* * *}$ \\
average education years & $0.224315^{* * *}$ & $0.136060^{* * *}$ & & -0.100416 \\
Primary education years & & & $-0.151893^{* * *}$ & 0.008167 \\
Secondary education years & & & 0.054367 & $0.191355^{* * *}$ \\
Higher education years & & & $0.198891^{* * *}$ & $1.056715^{* * *}$ \\
developed countries or not & & $1.064972^{* * *}$ & & $-0.082379^{* *}$ \\
Before or after 1973 & & $-0.141543^{* * *}$ & & 0.650926 \\
$\mathrm{R}^{2}$ & & 0.615248 & 0.964250 & 0.646401 \\
ADR & 0.958441 & 0.611699 & 0.959928 & 0.000000 \\
Goodness of fit value & 0.953606 & 0.000000 & 0.000000 & 143.8501 \\
\hline F statistic & 0.000000 & 428.0755 & 223.0892 & \\
\hline
\end{tabular}

Notes: Model 1 is fixed effects model without virtual variables, and only considers the average years of education. Model 2 is random effects model with no virtual variables, and only consider the average education years. Model 3 is a fixed effect model without virtual variables, and it divided education into three categories. Model 4 also divided education into three categories, and it is a random effects model with virtual variables. ${ }^{* *}$ indicates a significant level of $5 \%,{ }^{* * *}$ indicates a significant level of $1 \%$. 
Because other forms of capital, such as human capital, social capital, must rely on a certain amount of physical capital to realize the accumulation. As an important carrier, lacking of physical capital, economic growth will not be sustained.

The coefficients of life expectancy in model 1 and model 2 were significantly positive. Health capital is an important part of human capital, its importance is reflected as: 1 . healthy people can work longer hours, and they are more abundant and stronger in physical, mental or cognitive abilities, which could directly improve the labor productivity of the family and the market. Second, healthy people can enjoy a longer life, and they are more motivated to invest in their education. And a large amount of research on educational investment shows that education can improve individual's productivity and income greatly. Third, longer life expectancy promotes individual's savings at the production stage, which can reserve more monetary capital for economic investment, and further promote the income and economic growth. What's more, healthier workforce can also attract more foreign investment. Fourth, a healthier population means lower mortality rate, which reduces the need for a large number of home births, leading to lower population growth and increase the average age of the population [11]. Arora [12] tested the causal relationship between health and economic growth by using the time data of 10 industrialized countries since 1870. His findings suggest that in the long run, health has a significant positive impact on economic growth, but economic growth doesn't necessarily means the enhancement of health level. Bloom et al. [13] summarized 13 literatures on the relationship between health human capital and economic growth. The results show that all these researches proved the positive relationship between health human capital and economic growth. At the same time his own research suggests that the output elasticity of the average life expectancy was 0.04 , that is ,that is, if the average life expectancy is increased by one year, the country's output will be increased by 4 percentage points. Consistent with Arora, Bloom and other scholars' research, this article also believe that we should attach greater importance to the impact of health capital and life expectancy on economic growth.

Consistent with Soto et al. [14] and Wolff's research [15], results of this article also show that the average years of education and economic growth has a significant positive correlation, which offers another empirical proof of Endogenous Growth Theory. Romer model believes that the reason why some countries are always on a low-level growth-path is because the investment on knowledge production units is not enough, resulting in low technological progress rate. Therefore, we should encourage investment in knowledge production. Lucas believes that human capital is acquired through learning and education. The accumulation of human capital is different in different country, resulting in different economic growth rate and per capita output.

The coefficient of virtual variable 1 is positive in model 2, which shows that the developed degree has a significant impact on economic growth. Since 1 represents developed country, it shows that a country's economic development stock has positive impact for economic growth. The coefficient of virtual variable 2 is negative, which shows that the oil crisis of 1973 is a very important point for the world economy. The occurrence of oil crisis has major impact on the world economy, and the impact on economic growth is negative. Meanwhile, it also shows that setting this virtual variable is very meaningful.

As different education level has different influence on technological progress and efficiency, in order to further distinguish the effect of different levels of educational level on economic growth, We subdivided education into elementary education, secondary education and higher education, and analysis them with model 3 and model.

The coefficient of primary education in Model 3 is negative, and the $\mathrm{P}$ value is below the significance level of $5 \%$, therefore, primary education and economic growth has a high negative correlation. However, in model 4 where the virtual variable is included, the coefficient of primary education is not significant. The $\mathrm{P}$ value is 0.1320 , which shows an uncertain relationship between primary education and economic growth .The coefficients of secondary education in models 3 and 4 are not significant.

The relationship between primary education, secondary education and economic growth is uncertain. This may because that human capital with primary and secondary education is a kind of "immature" human capital, which does not necessarily promote economic growth. Human capital with primary or secondary education lacks professional learning in higher education, therefore their ability to learn and master new technology is relatively weak, which leads them into a situation which is lower than "the threshold level". Spiegel Benhabib's [16] model predicts that when a country's human capital level is lower than the "threshold level", it's total factor productivity (TFP) levels will fall behind the technology frontier countries further and further. Hua Ping [17] believes that once master the technology, education will become an important factor in deciding the adoption and mimic 
the application efficiency of new technology. If education has a positive effect on efficiency, the level of education can determine the technology's ability to absorb technology. People with higher education can make good management, and therefore improve the efficiency of technology applications, but people with primary education or secondary education may lack this kind of ability.

Higher education in model 3 and model 4 are both significant, and the coefficient is positive, which indicates that the human capital in the form of higher education can promote the economic development. This conclusion is consistent with the conclusion of Vandenbussche [8]. This might be the proof of the existence of "threshold effect" of human capital on economic growth. That is, only if human capital exceeds a certain threshold level, can it have a significant positive impact on economic growth. Rome once pointed out that the research and development sector in the economy is an important mechanism to maintain growth. The higher the quality of R \& $\mathrm{D}$ people is, the higher production will be. Workers with higher education are more prone to new ideas, new technologies and new products. It is easier for them to follow, adopt and apply technology that developed by the developed countries.

\subsection{Robustness Test}

We conducted a robustness test for the two models which have introduced virtual variables (model 2 and model 4), using two methods. First, we change the interval time period from five years to ten years. Second, we removed the maximum and the minimum values of the variables to conduct the robustness test (Table 4).

According to the results, life expectancy, material capital, the average years of education and the years of higher education all showed a positive correlation with economic growth in both tests, which is consistent with the original model. However, the P values of primary education and secondary education in the robustness test are both greater than 0.05 . This suggests that the relationship between primary education and secondary education and economic growth is uncertain, which is similar with the results of the original model. The robustness test results of the two virtual variables in are consistent with original mode, which showed significant negative correlation.

In conclusion, the robustness test results and the original model have the same direction. The change of the coefficient is little, which suggests the original model is robust.

\section{Conclusion and Implication}

First, based on our empirical analysis, we can see that whether it is developed country or developing country,

Table 4. Robust test results.

\begin{tabular}{ccccc}
\hline & $\begin{array}{c}\text { Ten years as a } \\
\text { period } \\
\text { Model 2a }\end{array}$ & $\begin{array}{c}\text { Remove the maximum and } \\
\text { the minimum values } \\
\text { Model 2b }\end{array}$ & $\begin{array}{c}\text { Ten years as a } \\
\text { period } \\
\text { Model 4a }\end{array}$ & $\begin{array}{c}\text { Remove the maximum and } \\
\text { the minimum values } \\
\text { Model 4b }\end{array}$ \\
\hline constant & $6.450871^{* * *}$ & $6.734000^{* * * *}$ & $7.911103^{* * * *}$ & $8.058620^{* * * *}$ \\
life expectancy & $0.038083^{* * *}$ & $0.033111^{* * *}$ & $0.027268^{* * *}$ & $0.024495^{* * * *}$ \\
Material capital & $0.011994^{* * *}$ & $0.011774^{* * *}$ & $0.012486^{* * *}$ & $0.011757^{* * *}$ \\
Average education years & $0.139950^{* * *}$ & $0.147887^{* * *}$ & - & - \\
Primary education years & - & - & -0.081370 & -0.090040 \\
Secondary education years & - & - & -0.002441 & -0.010305 \\
Higer education years & - & - & $0.231262^{* * *}$ & $0.200898^{* * * *}$ \\
Developed country or not & $1.004583^{* * *}$ & $1.059690^{* * *}$ & $0.980178^{* * *}$ & $1.061005^{* * *}$ \\
After or before 1973 & $-0.088996^{* *}$ & $-0.138110^{* * *}$ & -0.001886 & $-0.085713^{* *}$ \\
$\mathrm{R}^{2}$ & 0.647030 & 0.606933 & 0.664924 & 0.643619 \\
ADR & 0.640445 & 0.603252 & 0.656106 & 0.638921 \\
goodness of fit & 0.000000 & 0.000000 & 0.000000 & 0.000000 \\
F & 98.25440 & 164.9092 & 75.40698 & 136.9968 \\
Durbin-Watson statistics & 0.649614 & 0.287444 & 1.178971 & 0.325367 \\
\hline
\end{tabular}


education human capital and economic growth all showed a significant positive correlation. According to The World Bank, in the year of 2000, the world's average financial education funds is $4.4 \%$ of GDP; the average of high income countries is 5.3\%; the average of India also reached 4.1\%. However, in the year of 2012, China's financial education fund is still below $4 \%$ of GDP. This shows that the increase of education investment of our country is still in a relatively backward stage, and it directly leads to the backward situation of China's human capital, especially lack of innovative talents, which would further affects the development and stability of economic. Therefore, to promote the development of education, all levels of governments should raise the percentage of educational funds in the financial disbursement, optimize education expenditure structure and improve fund utilizing efficiency.

Second, there is a threshold effect in the relationship between education and economic growth. The results show that primary education and secondary education doesn't have significant positive impact on economic growth while higher education has significant positive effect on economic growth. This may be because that workers with higher education can better master new technology and have more innovative ability, which is extremely meaningful in today's world. Therefore, government public expenditure should pay more attention to higher education so that more teenagers can receive higher education and avoid entering labor market too early. Only in that way can we increase the proportion of labor force with higher education, and finally promote the economic development of our country.

Third, high-quality primary education and secondary education is the premise of high-quality higher education. For primary education, huge rural-urban disparity and regional disparity exist. Due to the shortage of funds, high dropout rate and loss of teachers are common phenomena in some underdeveloped areas. Therefore, government should increase the investment on primary education so that every citizen can enjoy equal high-quality primary education and to reduce illiteracy and semi illiteracy rate. Secondary education is a key link in the connection of primary education and higher education, which is also a stage that has always be ignored. Therefore, government should take a clear responsibility in this process and gradually increase the proportion of financial education funds.

Fourth, the empirical results of this article suggest that life expectancy, as an important part of human capital, has a direct impact on economic growth. With the continuous economic development and the continuous increase of people's income, people's demand for health is also increasing. As a result, the influence of healthy capital on the economic growth rate will be increasing. Therefore, to build a sound system of health care to promote the development of health capital will be an important determinant for the economic development in China.

\section{References}

[1] Temple, J.R.W. (2001) Generalizations That Aren't? Evidence on Education and Growth. European Economic Review, 45, 905-918. http://dx.doi.org/10.1016/S0014-2921(01)00116-7

[2] de la Fuente, Á. (2003) Human Capital in a Global and Knowledge-Based Economy. Part 2. Assessment at the EU Country Level. Recercat Principal.

[3] Afrooz, A., Rahim, K.B.A., Noor, Z.B.M. and Chin, L. (2010) Human Capital and Labor Productivity in Food Industries of Iran. International Journal of Economics \& Finance, 2, 47-51. http://dx.doi.org/10.5539/ijef.v2n4p47

[4] Aggrey, N. and Joseph, L.E.S. (2010) Human Capital and Labor Productivity in East African Manufacturing Firms. Current Research Journal of Economic Theory, 2, 48-54.

[5] Sonmez, F.D. and Sener, P. (2009) Effects of Human Capital and Openness on Economic Growth of Developed and Developing Countries: A Panel Data Analysis. World Academy of Science, Engineering and Technology, No. 30, 12421246.

[6] Krueger, A.B. and Lindahl, M. (2001) Education for Growth: Why and for Whom? Journal of Economic Literature, 39, 1101-1136. http://dx.doi.org/10.1257/jel.39.4.1101

[7] Bils, M. and Klenow, P.J. (2000) Does Schooling Cause Growth? American Economic Review, 90, 1160-1183. http://dx.doi.org/10.1257/aer.90.5.1160

[8] Vandenbussche, J., Aghion, P. and Meghir, C. (2006) Growth, Distance to Frontier and Composition of Human Capital, Journal of Economic Growth, 11, 97-127. http://dx.doi.org/10.1007/s10887-006-9002-y

[9] Mamuneas, T.P., Savvides, A. and Stengos, T. (2006) Economic Development and the Return to Human Capital: A Smooth Coefficient Semiparametric Approach. Journal of Applied Econometrics, 21, 111-132. http://dx.doi.org/10.1002/jae.813 
[10] Barro, R.J. and Lee, J.W.L. (2010) A New Data Set of Education Attainment in the World, 1950-2010. NBER Working Paper No.15902.National Bureau of Economic Research, 104, 184-198.

[11] Liu, C.S. and Jian, Y.F. (2011) Life Expectancy, Education Capital and Endogenous Economic Growth. Contemporary Finance and Economics, No. 4, 15-25.

[12] Arora, S. (2002) Health, Human Productivity, and Long-Term Economic Growth. Journal of Economic History, No. 3, 699-749.

[13] Bloom, D.E., Canning, D. and Sevilla, J. (2004) The Effect of Health on Economic Growth: A Production Function Approach. World Development, 32, 1-13. http://dx.doi.org/10.1016/j.worlddev.2003.07.002

[14] Cohen, D. and Soto, M. (2007) Growth and Human Capital: Good Data, Good Results. Journal of Economic Growth, 12, 51-76. http://dx.doi.org/10.1007/s10887-007-9011-5

[15] Wolff, E.N. (2000) Human Capital Investment and Economic Growth: Exploring the Cross-Country Evidence. Structural Change \& Economic Dynamics, 11, 433-472. http://dx.doi.org/10.1016/S0954-349X(00)00030-8

[16] Benhabib, J. and Spiegel, M. (2005) Human Capital and Technology Diffusion. Handbook of Economic Growth, 1, 935-966. http://dx.doi.org/10.1016/S1574-0684(05)01013-0

[17] Hua, P. (2005) The Effects of Different Educational Levels on the Growth of Total Factor Productivity: An Empirical Study from China's Provinces. Economics, No. 10, 147-165. 